\title{
Neglected bilateral congenital dislocation of the patella
}

\author{
İhmal edilmiş doğuştan iki taraflı patella çıkığı
}

\author{
Mehmet Ali Tokgöz, MD, Ali Turgay Çavuşoğlu, MD, Tacettin Ayanoğlu, MD, \\ Tarık Elma, MD, Abdurrahman Vural, MD \\ Department of Orthopedics and Traumatology, Medical Faculty of Gazi University, Ankara, Turkey
}

\begin{abstract}
Congenital dislocation of the patella is a disorder that presents with dysfunction in extensor mechanism. Although congenital dislocation of the patella mostly occurs in children with genetic disorders, it may also occur in totally healthy children, despite rarely. In this article, we report a 16 -year-old male patient who referred to our clinic with complaints of gait disturbance, frequent falls, and muscular weakness in lower extremity. The patient had no complaints during walking, but had difficulty in running and walking up and down the stairs. It was observed that the range of motion of the knee joint was completely painless and the quadriceps muscle strength was evaluated as $3 / 5$. An evaluation of computed tomography and magnetic resonance imaging results showed that the patella was dislocated. It became clear with magnetic resonance imaging that extensor mechanism was continuous but patellar tendon was not attached to its anatomical position. Surgical treatment was not planned because the patient did not describe any pain complaint and there was no limitation of joint movement, he could walk without support and without device and also refused to be operated. The choice of treatment should be based on the patient's preference, and pain and functional status.
\end{abstract}

Keywords: Congenital dislocation of the patella; nail-patella syndrome; neglected diseases.

Congenital dislocation of the patella is a disorder that presents with dysfunction in extensor mechanism. Lack of normal development in quadriceps femoris muscle and patella, intrauterine factors, muscle and fascia adhesions are implicated as etiological factors. ${ }^{[1]}$ Although congenital patella dislocation mostly occurs in children with genetic disorders such as Down syndrome, Osteo-Onychodysplasia, Rubinstein-Taybi and William-Beuren syndrome, it may also be seen rarely in healthy children. ${ }^{[2]}$
$\ddot{O Z Z}$

Doğuştan patella çıkı̆̆ı, ekstansör mekanizmada işlev bozukluğu ile ortaya çıkan bir hastalıktır. Doğuştan patella çıkığ 1 sıklıkla genetik bozukluğu olan çocuklarda gelişmekle birlikte, nadir de olsa tamamen sağlıklı çocuklarda da gelişebilir. Bu yazıda; yürüme bozukluğu, sık düşme ve alt ekstremitede kas güçsüzlüğü yakınmaları ile kliniğimize başvuran 16 yaşında bir erkek hasta sunuldu. Yürüme esnasında yakınması olmayan hasta koşarken ve merdiven inip çıkarken zorlanıyordu. Diz eklem hareket açıklığının tamamen ağrısız olduğu görüldü ve kuadriseps kası gücü $3 / 5$ olarak değerlendirildi. Bilgisayarlı tomografi ve manyetik rezonans görüntüleme sonuçları değerlendirildiğinde, patellanın çıkık olduğu görüldü. Manyetik rezonans görüntüleme ekstansör mekanizmanın devamlı olduğunu ama patellar tendonun anatomik yerine tutunmadığını ortaya koydu. Hastanın belirgin ağrı yakınması ve eklem hareket kısitlılığı olmaması, desteksiz ve cihazsız yürüyebilmesi ve ameliyat olmayı reddetmesi nedeniyle cerrahi tedavi planlanmadi. Tedavi seçimi hastanın tercihine ve ağrı ve işlevsel durumuna dayandırılmalıdır.

Anahtar sözcükler: Doğuştan patella çıkığı; tırnak-patella sendromu; ihmal edilmiş hastalıklar.

In this article, we report a male patient who presented with complaints of gait disturbance, frequent falls, and muscle weakness in the lower extremity. It was established that he had no limitation in joint movement and could walk without any support. With physical examination and radiological investigations, congenital dislocation of the patella was diagnosed. This case report aims to present and discuss the clinical and radiological characteristics of this patient.

- Received: December 21, 2016 Accepted: February 13, 2017

- Correspondence: Mehmet Ali Tokgöz, MD. Gazi Üniversitesi Tıp Fakültesi Ortopedi ve Travmatoloji Anabilim Dalı, 06500 Beşevler, Ankara, Turkey. Tel: +90 312 - 2024710 e-mail: m.alitokgoz@gmail.com 

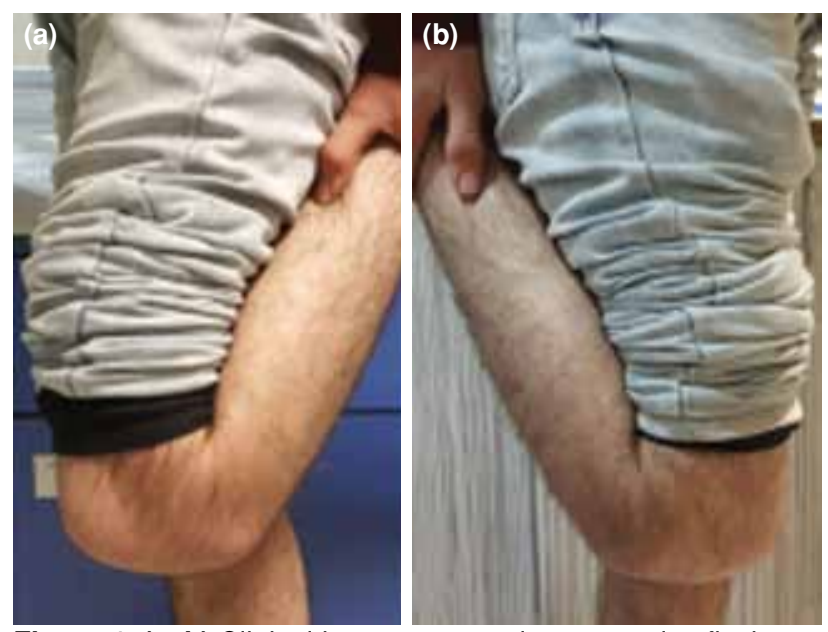

Figure 1. (a, b) Clinical images on maximum passive flexion.

\section{CASE REPORT}

A 16-year-old male patient referred to our clinic with complaints of gait disturbance, frequent falls, and muscular weakness in lower extremity. The patient reported no complaints during walking, but indicated difficulty in running and walking up and down the stairs. There was no similar family history or comorbid disease, or no accompanying systemic-genetic origin pathology. When we questioned patient's relevant history, we learned that he started to walk at the age of one and underwent examination in other centers until the age of 13 with complaints of weakness in knee and falls. A written informed consent was obtained from the patient.

The patient was capable of walking without any support or device and there was no disruption during walk. In the inspection of anterior aspect of knee, although knee seemed to have normal alignment, patella groove was observed to be empty in both knees and patella was found to be present in lateral and superior of femoral groove in both flexion and extension. Thigh region was seen to be atrophic. Range of motion of the knee joint was complete and painless. Both sides were actively able to bring their knees to full extension and there was no limitation of extension. Both knee joints could undergo flexion until 150 degrees (Figure 1). In examination of motor movement, it was determined that he could resist gravity but could exert only minimal force against opposing forces, hence motor force of quadriceps muscle was evaluated as 3/5. Patellar reflex could not be elicited, which was attributed to the fact that patella was not in its anatomical position.

In anterior-posterior, lateral and tangential images of patellar X-rays, patella was not found in its anatomical groove (Figures 2 and 3). Hence patellar agenesis was considered and bone structure was evaluated with computed tomography (Figure 4) while extensor mechanism was evaluated with magnetic resonance imaging (MRI) (Figure 5). Patella was seen to be rudimentary and in superolateral dislocated position. It became clear with MRI that extensor mechanism was continuous but patellar tendon was not attached to its anatomical position.

Surgical treatment was not planned because the patient did not describe any pain complaint and there was no limitation of joint movement, he could walk without support and without device and also refused to be operated. Instead, conservative treatment was considered with quadriceps strengthening exercises and life-style modifications.

\section{DISCUSSION}

Embryonic development of knee is completed at the eighth week of gestation, but the growth of patellofemoral joint continues decreasingly until
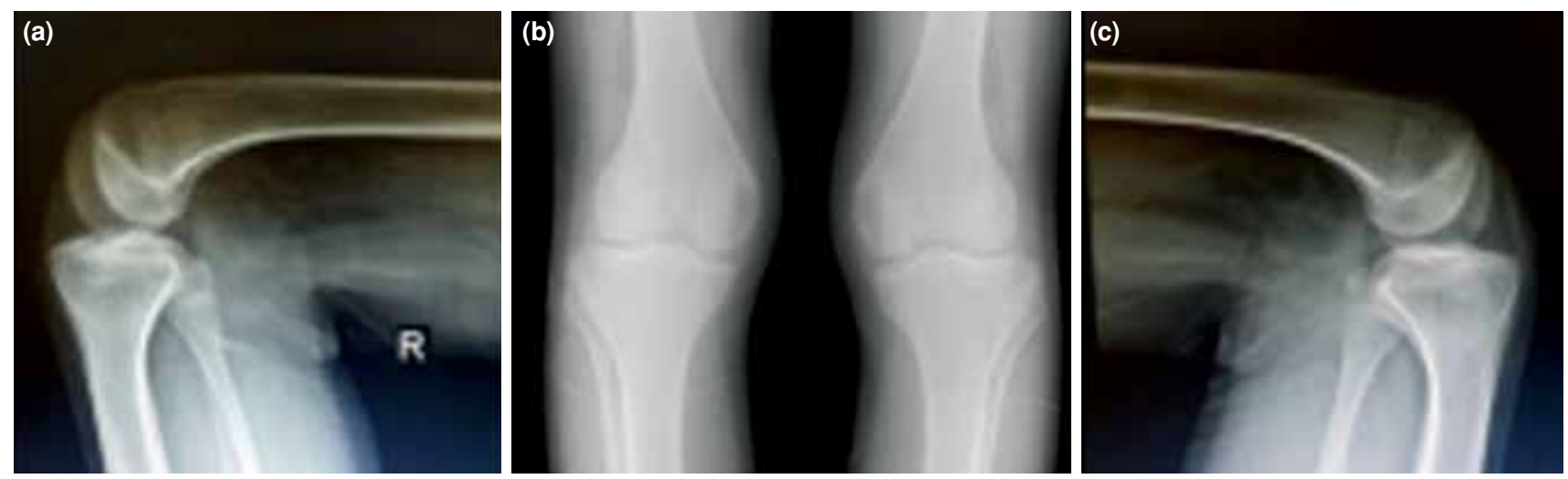

Figure 2. (a-c) Anterior-posterior and active flexion of lateral knee radiographs. Patella was not found in its anatomical groove. 


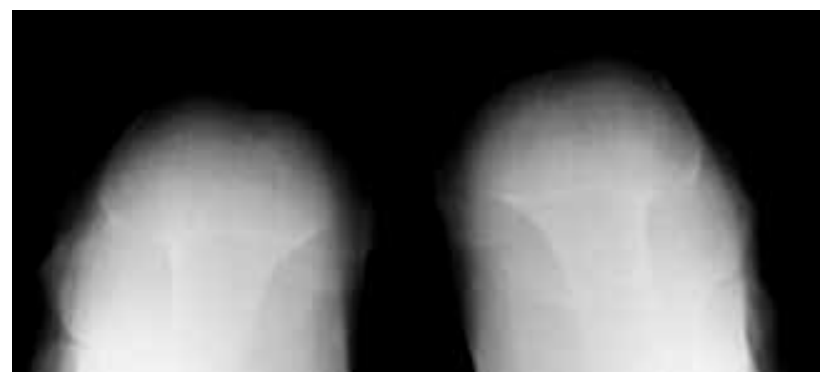

Figure 3. Tangential patellar radiographs taken on both knees. Dislocated patella found in lateral part of knee.

puberty with hormonal effects. Its development results as a sesamoid bone within extensor mechanism of knee. Advanced patellofemoral disorders may be the result of ossification problems. In early childhood, there may be no cosmetic or functional complaints. However, in older ages, weakness in lower extremity, progressive genu valgum, external tibial rotation and flexion deformity may develop. Pain is a late period finding arising as a consequence of arthrosis development. Patellar ossification starts at the age of three-four; therefore, radiographies do not help diagnosis until this age. In suspicious cases, MRI should be used. ${ }^{[3]}$
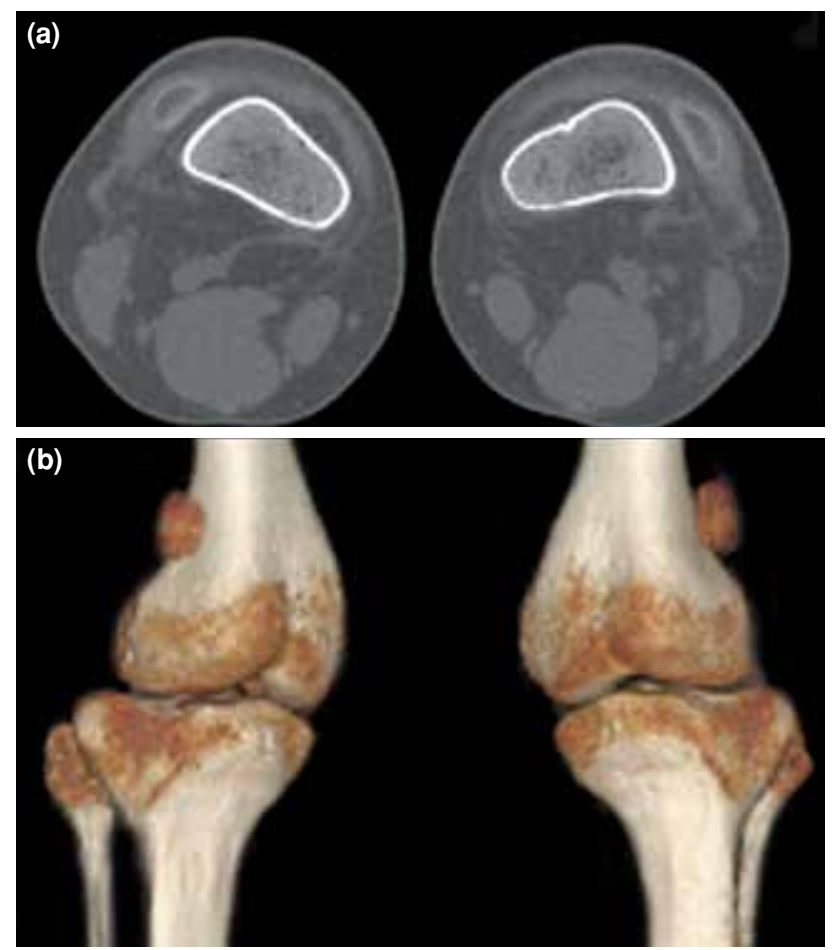

Figure 4. Right and left knee (a) computed tomography and (b) three-dimensional computed tomography imaging. Patella was seen to be rudimentary and in superolateral dislocated position.
Congenital dislocation of the patella, in which patellar development proceeds but alignment is not correct, may occur as part of osteo-onychodysplasia, Rubinstein-Taybi, and Williams-Beuren syndromes, but it may also occur isolated as in the present case..$^{[4]}$ Patellar ossification continues until puberty, which leads to delay in diagnosis, since, even if the patella is not in proper position, the time of the first walk of the child may not change. However, due to weakness in extensor mechanism, imbalance and history of frequent falls may be described.

Delayed diagnosis may cause knee pain and development of patellofemoral arthrosis, although it has not developed yet in the present case..$^{[5]}$

Most cases, particularly the ones which are syndromic, are recognized in childhood and treated. However, isolated patella dislocation may be missed and these cases may be encountered after the development of skeletal maturation. Choice of treatment may be established depending on the functional condition of the patient. In a publication including patients with a mean joint flexion of 65 degrees, patients were treated surgically and reported an increased flexion capacity. ${ }^{[6]}$ In the present case, knee was capable of hyperflexion (150 degree) and joint movement limitation was not present. Orthopedics and traumatology specialists are primarily surgeons, but we need to remember that we are also physicians. In many cases, surgical option is neither urgent nor necessary and conservative treatment is good enough. ${ }^{[7]}$

In the late period, knee might progress to osteoarthritis with its patella that proceeds to valgus and comes to a closed unreducible position, where some surgeons prefer arthroplasty options as treatment method. The most important decision that should be made here is the procedure that will be performed on extensor mechanism. Patella may be reduced or may be followed in the same manner after surgery. ${ }^{[8]}$

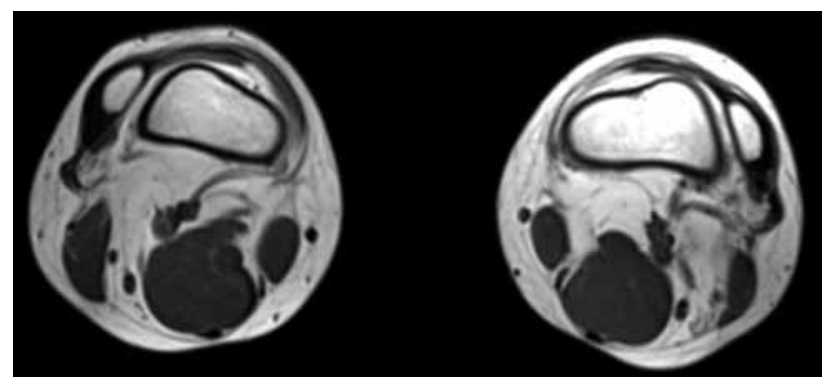

Figure 5. Right and left knee magnetic resonance imaging. 
In these cases, future degenerative and functional problems cannot be predicted earlier. On the other hand, using aggressive surgical methods in such cases can cause problems during and after surgery. Patients without limitation of joint motion prior to surgery may experience motion restriction after surgery. In these patients, quadriceps muscle is weak and often shortened. The hamstring muscles may be shortened and the posterior knee capsule may be contracted..$^{[9]}$ After the surgery, thigh muscles may become less functional due to postoperative immobility and the surgical technique. For this reason, the treatment of patients who have completed skeletal maturation must be carefully planned and be individualized. The present case had no joint movement limitation and mobilization problem. In addition, the fact that the patient did not accept surgical treatment led us to try conservative treatment.

In conclusion, newborns, particularly syndromic children, should be evaluated for the development of the extensor mechanism. Physical and advanced radiological examinations may assist in recognizing this rare condition in the early period.

\section{Declaration of conflicting interests}

The authors declared no conflicts of interest with respect to the authorship and/or publication of this article.

\section{Funding}

The authors received no financial support for the research and/or authorship of this article.

\section{REFERENCES}

1. Koplewitz BZ, Babyn PS, Cole WG. Congenital dislocation of the patella. AJR Am J Roentgenol 2005;184:1640-6.

2. Gardner E, O'Rahilly R. The early development of the knee joint in staged human embryos. J Anat 1968;102:289-99.

3. Jevic SS, Zemenick G, Miller D. Congenital, irreducible, permanent lateral dislocation of the patella. Clin Orthop Relat Res 1976;116:190-9.

4. Miguel Sá P, Raposo F, Santos Carvalho M, Alegrete N, Coutinho J, et al. Congenital dislocation of the patella clinical case. Rev Bras Ortop 2015;51:109-12.

5. Şahin O, Kıral M, Arık M. Doğuştan patellofemoral eklem sorunları. TOTBIDD Dergisi 2012;11:366-71.

6. Yoshvin S, Southern EP, Wang Y. Surgical treatment of congenital patellar dislocation in skeletally mature patients: surgical technique and case series. Eur J Orthop Surg Traumatol 2015;25:1081-6.

7. Atik OŞ. Do we surgeons perform surgery only? Eklem Hastalik Cerrahisi 2016;27:123-4.

8. Yamanaka H, Kawamoto T, Tamai H, Suzuki M, Kobayashi T, Eguchi $Y$, et al. Total knee arthroplasty in a patient with bilateral congenital dislocation of the patella treated with a different method in each knee. Case Rep Orthop 2015;2015:890315.

9. Noordin S, Allana S, Wright JG. Surgical management of neglected bilateral obligatory patella dislocation. J Pediatr Orthop B 2010;19:337-40. 